\title{
IDENTYFIKACJA I PORÓWNANIE KRYTERIÓW OCENY WIARYGODNOŚCI WITRYN INTERNETOWYCH
}

https://doi.org/10.33141/po.2019.08.07

Adam Czerwiński

\author{
Przegląd Organizacji, Nr 8 (955), 2019, ss. 50-58 \\ www.przegladorganizacji.pl \\ @Towarzystwo Naukowe Organizacji i Kierownictwa
}

(TNOiK)

\section{Wprowadzenie}

0 d wielu lat można zaobserwować ogromny przyrost ilości informacji gromadzonych, przetwarzanych, udostępnianych i wykorzystywanych przez współczesne organizacje oraz społeczeństwo informacyjne za pośrednictwem Internetu. Dzięki swoim walorom, m.in. powszechności, otwartości i technologicznej standaryzacji, Internet stał się podstawą współczesnej globalnej pamięci. Często znajdują się tam bardzo cenne informacje o produktach, zdrowiu, finansach, polityce, edukacji, kulturze i wiele innych. Treści zamieszczone na witrynach internetowych są wykorzystywane przez przedsiębiorstwa i organizacje oraz użytkowników do dalszego przetwarzania lub podejmowania decyzji, których skutki społeczne, ekonomiczne i polityczne są nierzadko bardzo ważne oraz długotrwałe. Między innymi dlatego konieczne jest zarządzanie jakością zasobów informacyjnych w Internecie (Czerwiński, Krzesaj, 2018, s. 25). Chociaż w sieci istnieje bardzo wiele użytecznych informacji, to nadal mnożą się witryny wprowadzające $\mathrm{w}$ błąd, zawierające informacje niepoprawne albo wręcz szkodliwe. Może to doprowadzić organizacje do poważnych strat finansowych albo narazić na szwank ich dobre imię i wizerunek, a użytkowników do utraty zdrowia, a nawet życia czy utraty tożsamości (Schwarz, Morris, 2011, s. 1245). Dlatego ocena jakości i wiarygodności witryn internetowych jest tak istotna dla dostawców treści, administratorów oraz użytkowników tych witryn. Taka ocena może być dokonywana z perspektywy zasobów informacji. Z tego punktu widzenia M.J. Eppler (2006, s. 65-69) proponuje użycie ram jakości informacji, które obejmują cztery etapy: identyfikację, ocenę, alokację i aplikację. Celem tych ram jest strukturyzacja działań związanych z zarządzaniem jakością informacji i tworzeniem wartości dodanej. M.J. Eppler łączy zatem zarządzanie jakością informacji (w tym wiarygodnością) i zarządzanie informacjami poprzez wykorzystanie cyklu życia informacji. Celem zarządzania informacją na witrynie może być $\mathrm{z}$ kolei dostarczenie wysokiej jakości zasobów informacyjnych. R. Wang (1998, s. 61-65) proponuje $\mathrm{w}$ takim przypadku metodykę opartą o całościowy model zarządzania jakością danych (ang. Total Data Quality Management - TDQM), która składa się z czterech etapów: definiowania, mierzenia, analizy i doskonalenia. Celem TDQM jest dostarczanie konsumentom wysokiej jakości produktów informacyjnych.
R. Wang (1998) łączy więc zarządzanie jakością informacji (w tym wiarygodnością) i zarządzanie jakością, biorąc pod uwagę informacje jako produkt systemu informacyjnego. Obie opisywane metodyki wymagają jednoznacznej identyfikacji i zdefiniowania kryteriów oceny jakości informacji (w tym wiarygodności). Dokonuje się jej jednak w środowisku internetowym, które charakteryzują następujące najważniejsze cechy (Knight, Burn, 2005, s. 167-168):

- jest ono bardzo rozległe w zakresie treści i struktur;

- rozwija się, jest dynamiczne;

- nie ma w nim możliwości egzekwowania norm jakościowych podczas zamieszczania informacji (wynika to m.in. $\mathrm{z}$ anonimowości i łatwości ich zamieszczania);

- jest niebezpieczne z elementami składowymi podatnymi na awarie i ataki.

Powoduje to konieczność dostosowania zidentyfikowanych kryteriów oceny wiarygodności do tego środowiska. Do tego zadania można jednak podejść w różny sposób. Prowadzi to do uzyskania znacząco odmiennych zestawów kryteriów, zarówno co do ich liczebności, jak i zakresu, a nawet obszaru i przedmiotu podlegającego ocenie. Użytkownik witryny czy też jej administrator albo dostawca informacji dokonujący oceny wiarygodności staje wówczas przed problemem odpowiedniości i ogólności proponowanego zestawu kryteriów ewaluacji. W literaturze przedmiotu ten aspekt oceny wiarygodności witryn internetowych nie był dotychczas podnoszony.

Dlatego celem artykułu jest zarówno ukazanie, jak i porównanie różnych, znanych zestawów kryteriów oceny wiarygodności witryn/serwisów internetowych. Podstawowe pytania badawcze postawione w pracy brzmią:

a) czy stosując odmienne podejścia do identyfikacji i definiowania kryteriów oceny wiarygodności witryn internetowych można uzyskać takie ramy oceny, które są: - ogólne, tzn. muszą dawać możliwość oceny wiarygodności występującej we wszystkich procesach informacyjnych w sieci Internet;

- odpowiednie, tzn. muszą dawać możliwość oceny wiarygodności w procesach realizowanych przez podmioty występujące w różnych rolach (dostawców informacji, administratorów informacji, użytkowników informacji);

- elastyczne, tzn. muszą dawać możliwość oceny wiarygodności witryn realizujących swoje zadania 
w różnych obszarach (np. w produkcji, handlu, ubezpieczeniach, bankowości, kształceniu, działalności publicznej itd.);

b) czy prowadzi to do stworzenia rozmaitych zestawów tych kryteriów?

Aby odpowiedzieć na postawione pytania badawcze, najpierw pokazano możliwe podejścia do identyfikacji kryteriów oceny wiarygodności witryn: intuicyjne, teoretyczne i empiryczne. $\mathrm{Na}$ tej podstawie przedstawiono celowo dobrane przykłady zestawów kryteriów oceny wynikające z zastosowanego podejścia. Następnie, stosując metodę analizy porównawczej pokazano, na ile są one zróżnicowane, oraz wskazano, które z nich są ogólne, odpowiednie i elastyczne.

Wyniki porównania różnych zestawów kryteriów oceny wiarygodności mogą być wykorzystane w praktyce do konstrukcji różnych narzędzi oceny wiarygodności witryn/serwisów internetowych.

\section{Pojęcie wiarygodności witryny internetowej}

B iorąc pod uwagę przedstawione w pracach (Czerwiński, 2016a, 2016b) rozważania, wiarygodność witryny internetowej oznacza przeświadczenie użytkownika, że jego oczekiwania dotyczące otrzymania określonych informacji $\mathrm{z}$ tej witryny (serwisu internetowego) zostaną spełnione bez ponoszenia dodatkowych, nieuzasadnionych kosztów (ekonomicznych, społecznych, psychologicznych, prawnych, etycznych).

Dokonując ewaluacji wiarygodności witryn internetowych, należy zidentyfikować i zdefiniować wymiary oraz kryteria oceny. W literaturze występują różne kategoryzacje wymiarów zaufania. Formułuje je wielu badaczy, m.in. P.M. Doney i J.P. Cannon, S. Ganesan, D. Gefen, K. Giffin, R.E. Larzelere i T.L. Huston (Gefen i in., 2003; Gefen, 2002). Najczęściej spotykana ogólna struktura obejmuje trzy wymiary zaufania: zdolność (ability), życzliwość (benevolence) i uczciwość (integrity). Zostały one wykorzystane przez autora niniejszego tekstu do stworzenia ram oceny wiarygodności witryn internetowych, opisanych w dalszej części artykułu. Z kolei T. Lucassen i inni (2013, s. 255-256) zaproponowali tzw. model 3S, w którym istnieją trzy strategie oceny wiarygodności stron internetowych: i) biorąc pod uwagę funkcje semantyczne, takie jak dokładność lub bezstronność, ii) wyróżniając cechy związane z projektem witryny, takie jak wygląd strony internetowej, jej estetyka czy kolorystyka tekstu oraz iii) identyfikując wcześniejsze doświadczenia użytkownika ze źródłem, np. opinie na temat właściciela (sponsora) witryny lub jego powiązań. Ten model również pozwala na identyfikację czynników i kryteriów oceny wiarygodności witryn.

\section{Podejścia do identyfikacji kryteriów wiarygodności}

D o identyfikacji i definiowania kryteriów oceny wiarygodności witryn można zastosować trzy następujące podejścia: intuicyjne, teoretyczne i empiryczne (Wang,
Strong, 1996). Intuicyjne podejście polega na wykorzystaniu doświadczeń badaczy i wymagań w konkretnych zastosowaniach. W tym podejściu kryteria wiarygodności informacji są identyfikowane zgodnie z określonymi kontekstami, na przykład w celu podejmowania decyzji (O'Reilly III, 1982) albo w celu modelowania niedoborów wiarygodności na witrynach (Ballou, Pazer, 1985). Natomiast kryteria te są definiowane z punktu widzenia danych. Na przykład kompletność informacji na witrynie oznacza stan, w którym wszystkie wartości danej zmiennej są zapisane.

Teoretyczne podejście polega na identyfikacji kryteriów wiarygodności witryn w oparciu o braki w danych występujące w procesie ich przetwarzania. Poszczególne kryteria oceny wiarygodności witryn można zidentyfikować poprzez obserwowanie niespójności między systemem rzeczywistym a opisującym go systemem informacyjnym w sieci (Wand, Wang, 1996). W tym podejściu kryteria oceny są definiowane z perspektywy świata rzeczywistego. Na przykład kompletność informacji na witrynie jest definiowana odmiennie niż poprzednio jako zdolność internetowego systemu informacyjnego do reprezentowania każdego znaczącego stanu świata rzeczywistego.

Z kolei podejście empiryczne pozwala zidentyfikować i zdefiniować kryteria wiarygodności z punktu widzenia użytkownika, koncentrując się na tym, czy informacje na witrynie są dla niego użyteczne (Wang, Strong, 1996). $\mathrm{W}$ tej sytuacji, definiując poszczególne kryteria, zwraca się uwagę na stan odpowiednich cech i własności w kontekście rozwiązania zadania stojącego przed użytkownikiem, np. podjęcia określonej decyzji.

W ramach tych podejść, za pomocą metody doboru celowego, wybrano przykładowe zestawy kryteriów oceny wiarygodności i następnie, stosując metodę analizy porównawczej, dokonano ich porównania w kontekście postawionych pytań badawczych.

\section{Przykładowe zestawy kryteriów oceny wiarygodności i ich porównanie}

$\mathbf{P}$ rzykładem podejścia intuicyjnego są ramy oceny wiarygodności witryn zaproponowane przez A. Czerwińskiego (2016a). Zaprezentowana przez autora struktura wymiarów oraz kryteriów zaufania ma na celu zwiększanie wiarygodności witryn internetowych i opiera się na doświadczeniach wielu badaczy. $\mathrm{Na}$ tej podstawie przyjęto trzy zaproponowane wyżej wymiary zaufania: zdolność, życzliwość i uczciwość. W zastosowaniu do witryn internetowych zdolność oznacza przekonanie użytkownika, że witryna/serwis internetowy jest w stanie dostarczyć oczekiwane treści. Życzliwość jest wymiarem dotyczącym gotowości właściciela witryny do zaspokojenia potrzeb użytkownika i dbania o jego satysfakcję nawet, jeżeli będzie to związane $\mathrm{z}$ dodatkowymi kosztami. Uczciwość odzwierciedla przekonanie użytkownika, że witryna przestrzega przepisów prawnych, zasad etycznych oraz standardów branżowych. W tych trzech wymiarach zaufania 
zidentyfikowano 18 kryteriów oceny wiarygodności witryn (Czerwiński, 2016a, s. 47).

Jak już wspomniano, wymiar „zdolność” ściśle wiąże się z użytecznością witryny, która może zostać oceniona przez użytkownika na podstawie takich kryteriów, jak: (W1) Funkcjonalność, (W2) Bezpieczeństwo, (W3) Przejrzystość i (W4) Elastyczność. Jednak z drugiej strony użytkownik witryny musi być „zdolny” do wykorzystania zawartych na niej treści. Dlatego w ramach tego wymiaru uwzględniono także cechy użytkownika, takie jak: (W5) Doświadczenie, (W6) Nawyki, (W7) Styl życia i (W8) Prywatność, które charakteryzują kontekst rozwiązywanego zadania od strony użytkownika.

W wymiarze „życzliwość" kryteria oceny wiarygodności stanowią: (W9) Wydajność, (W10) Niezawodność, (W11) Dostępność danych, (W12) Bogactwo informacji, (W13) Jakość informacji, które charakteryzują infrastrukturę służącą do dostarczania informacji oraz wewnętrzne jej cechy. W wymiarze „uczciwość” znajdują się takie kryteria oceny, jak: (W14) Autentyczność, (W15) Referencje, (W16) Wierność, (W17) Solidność (Rzetelność) i (W18) Poszanowanie cudzej własności. Opisany zestaw kryteriów został w dalszych porównaniach oznaczony jako $\mathbf{W}$.

Dokonując operacjonalizacji oceny wiarygodności witryn internetowych, trzeba wskazać mierniki zaprezentowanych kryteriów, uwzględniające pięć aspektów: techniczny, ergonomiczny, graficzny, komunikacyjny i społeczny. Daje to możliwość wyboru bardzo wielu różnych miar lub wskaźników oceny wiarygodności (Czerwiński, 2016a, s. 47).

Pewne elementy podejścia teoretycznego do identyfikacji i definiowania kryteriów wiarygodności można zauważyć wśród badaczy, którzy wykorzystują podejście empiryczne. Chodzi tu głównie o obserwowanie i analizowanie niespójności między stanem systemu rzeczywistego a opisującym go systemem informacyjnym w Internecie na podstawie komentarzy użytkowników witryn. Prowadzi to w konsekwencji do identyfikacji kryteriów wiarygodności wyłącznie z punktu widzenia użytkownika, a nie procesu przetwarzania danych. Dlatego teoretyczne podejście w „czystej postaci” w zasadzie nie występuje.

Natomiast podejście empiryczne jest najliczniej wykorzystywanym podejściem do identyfikacji i definiowania kryteriów wiarygodności. Reprezentują je m.in. autorzy często cytowanego badania wiarygodności witryn realizowanego $\mathrm{z}$ punktu widzenia użytkowników (Fogg i in., 2003). Uczestnicy tego badania (2684 osób) dokonywali oceny losowej pary witryn w określonej kategorii wybranej spośród 10 wziętych pod uwage przez badaczy. Ewaluacja polegała na wskazaniu, która z nich jest bardziej lub mniej wiarygodna. Oceniający mogli swoją ocenę uzasadnić, wpisując komentarz. Uzyskano w ten sposób 2440 komentarzy dotyczących ocenianych witryn. Analiza ich treści przez ekspertów pozwoliła wyłonić określone, powtarzające się kryteria oceny. Były to: (F1) Wygląd, (F2) Projekt/struktura informacji, (F3) Skupienie informacji, (F4) Motywy firmy/właści- ciela, (F5) Przydatność informacji, (F6) Dokładność informacji, (F7) Rozpoznawalność nazwy i reputacja witryny, (F8) Reklama na witrynie, (F9) Stronniczość informacji, (F10) Ton witryny, (F11) Tożsamość operatora/sponsora strony, (F12) Funkcjonalność strony, (F13) Obsługa klienta, (F14) Dotychczasowe doświadczenia z witryną, (F15) Jasność informacji, (F16) Wyniki w teście użytkownika, (F17) Czytelność, (F18) Afiliacje. Ten zestaw kryteriów oznaczono dalej jako F.

W tabeli 1 porównano zestawy $\mathbf{W}$ (wiersze) i $\mathbf{F}$ (kolumny) kryteriów oceny wiarygodności witryn. Znakiem „X” oznaczono te kryteria, które występują w obydwu zestawach (mają identyczną albo niemal taką samą interpretację). Kolorem szarym zaznaczono kryteria, które nie mają swoich odpowiedników w drugim zestawie.

Zestaw W kryteriów pokrywa 77,8\% kryteriów z zestawu F, zaś zestaw F kryteriów pokrywa tylko $66,7 \%$ kryteriów z zestawu W. Z porównania wynika, że w zestawie F kryteriów brak jest sześciu kryteriów występujących w zestawie W. Są to: (W3) Przejrzystość, (W4) Elastyczność, (W5) Doświadczenie, (W7) Styl życia, (W8) Prywatność, (W10) Niezawodność. Ten brak jest zupełnie zrozumiały w odniesieniu do kryteriów, które charakteryzują zdolność użytkownika do wykorzystania treści zawartych na witrynach (tzn. W5, W7, W8). Kryteria z zestawu F zostały bowiem zidentyfikowane na podstawie komentarzy użytkowników podczas ewaluacji witryn, a te nie obejmowały ich kompetencji czy stylu życia. Kryterium, którego nieobecność w zestawie F zaskakuje, jest niezawodność. To kryterium wiąże się jednak z oceną infrastruktury dostarczającej informacji za pośrednictwem witryny (nie dotyczy zawartych na niej treści) i dlatego być może nie było wskazywane przez użytkowników.

Z kolei w zestawie $\mathbf{W}$ brak jest czterech kryteriów występujących w zestawie F. Są to: (F8) Reklama na witrynie, (F9) Stronniczość informacji, (F10) Ton witryny i (F13) Obsługa klienta. Wszystkie te kryteria ściśle wiążą się z celami i zadaniami witryny postawionymi przez jej właścicieli/sponsorów. Nie podlegały one ocenie w zestawie W, gdyż nie mogły być ujęte w żadnym z trzech wymiarów ewaluacji, które przyjęto intuicyjnie. Pokazuje to konieczność uzupełnienia zestawu kryteriów zaproponowanego przez A. Czerwińskiego o czwarty wymiar związany $\mathrm{z}$ celami i zadaniami witryny.

Autorzy innych badań wiarygodności witryn wśród użytkowników M. Kąkol i R. Nielek (2015) znacząco poszerzyli ich zakres. W tym przypadku 2041 uczestników badania dokonało oceny 5543 stron, uzyskując 15750 ocen. Autorom chodziło głównie o sprawdzenie, w jaki sposób zmiany w technologii i środowisku społecznym znajdują odzwierciedlenie $\mathrm{w}$ procesie oceny wiarygodności witryn internetowych przez użytkowników. W celu identyfikacji dokonującej się transformacji kryteriów oceny wiarygodności, zastosowano dwuetapowe, półautomatyczne podejście do wyników przeprowadzonego badania. W pierwszym etapie uży- 
Tabela 1. Porównanie zestawu kryteriów wiarygodności według B.J. Fogga i in. (F1 do F18) oraz A. Czerwińskiego (W1 do W18)

\begin{tabular}{|c|c|c|c|c|c|c|c|c|c|c|c|c|c|c|c|c|c|c|}
\hline & $\mathrm{F} 1$ & F2 & F3 & $\mathrm{F} 4$ & F5 & F6 & F7 & F8 & F9 & F10 & F11 & F12 & F13 & F14 & F15 & F16 & F17 & F18 \\
\hline W1 & & & & & & & & & & & & $X$ & & & & & & \\
\hline W2 & $\mathrm{X}$ & $\mathrm{X}$ & & & & & & & & & & & & & $\mathrm{X}$ & & $\mathrm{X}$ & \\
\hline W3 & & & & & & & & & & & & & & & & & & \\
\hline W4 & & & & & & & & & & & & & & & & & & \\
\hline W5 & & & & & & & & & & & & & & & & & & \\
\hline W6 & & & & & & & & & & & & & & $\mathrm{X}$ & & & & \\
\hline W7 & & & & & & & & & & & & & & & & & & \\
\hline W8 & & & & & & & & & & & & & & & & & & \\
\hline W9 & & & & & & & & & & & & & & & & $\mathrm{X}$ & & \\
\hline W10 & & & & & & & & & & & & & & & & & & \\
\hline W11 & & & $\mathrm{X}$ & & & & & & & & & & & & & & & \\
\hline W12 & & & $\mathrm{X}$ & & & & & & & & & & & & & & & \\
\hline W13 & & & & & $\mathrm{X}$ & $\mathrm{X}$ & & & & & & & & & $\mathrm{X}$ & & & \\
\hline W14 & & & & & & & & & & & $\mathrm{X}$ & & & & & & & $\mathrm{X}$ \\
\hline W15 & & & & & & & $\mathrm{X}$ & & & & & & & & & & & \\
\hline W16 & & & & $\mathrm{X}$ & & & & & & & & & & & & & & \\
\hline W17 & & & & $\mathrm{X}$ & & & & & & & & & & & & & & \\
\hline W18 & & & & $X$ & & & & & & & & & & & & & & \\
\hline
\end{tabular}

Źródło: opracowanie własne

to metod grupowania tekstu w jakościowych ocenach wiarygodności, aby uzyskać silnie rozłączne grupy terminów i tematów ocen. Uzyskany słownik, zawierający listę opisowych terminów oceny, posłużył w drugim etapie do ręcznego przypisywania ocen. Ostatecznie analiza danych ujawniła 23 kryteria oceny wiarygodności (C1 do C23), które pogrupowano w sześć wymiarów (wobec trzech w zestawie W). Są to:

- Co to jest? (C1) Rodzaj treści internetowych, (C2) Plotki o gwiazdach, (C3) Źródło wiadomości, (C4) Badania naukowe.

- Czy ma to charakter komercyjny? (C5) Reklama, (C6) Oferta sprzedaży.

- Kto jest autorem lub wydawca? (C7) Podpisany autor, (C8) Znany Autor/Autorka, (C9) Oficjalna strona, (C10) Jakie jest źródło?

- Jak to wyglada? (C11) Uszkodzone linki, (C12) Wiele linków, (C13) Dostępne informacje kontaktowe, (C14) Organizacja treści, (C15) Projekt/Wygląd.

- Czy łatwo jest to czytać? (C16) Dokument/tekst łatwy do odczytania, (C17) Dobrze napisany tekst - poprawny język, (C18) Informacyjność, kompletność.
- Czy można to zweryfikować? (C19) Czy łatwo to wyszukać? (C20) Obiektywność - opinia osobista, recenzja, (C21) Odniesienia - odwołania do wiarygodnych źródeł, (C22) Aktualność, data publikacji, (C23) Doświadczenie użytkownika.

Ten zestaw kryteriów oznaczono dalej jako C.

W tabeli 2 porównano zestawy $\mathbf{C}$ (wiersze) i $\mathbf{F}$ (kolumny) kryteriów oceny wiarygodności witryn. Znakiem "X” oznaczono te kryteria, które występują w obydwu zestawach. Kolorem szarym zaznaczono kryteria, które nie mają swoich odpowiedników w drugim zestawie.

Zestaw C pokrywa 100\% kryteriów z zestawu F. Z kolei zestaw kryteriów F pokrywa tylko 65,2\% kryteriów z zestawu C. Z porównania wynika, że w zestawie $\mathbf{F}$ w brak jest aż ośmiu kryteriów występujących w zestawie C. Są to: (C1) Rodzaj treści internetowych, (C2) Plotki o gwiazdach, (C3) Źródło wiadomości, (C4) Badania naukowe, (C12) Wiele linków, (C19) Czy łatwo to wyszukać? (C21) Odniesienia - odwołania do wiarygodnych źródeł, (C22) Aktualność, data publikacji. Ujawnione różnice wynikają głównie z faktu, $\dot{z}$ e $\mathrm{w}$ badaniach przeprowadzonych przez B.J. Fogga 
Tabela 2. Porównanie zestawu kryteriów wiarygodności według B.J. Fogga i in. (F1 do F18) oraz M. Kąkola i R. Nielka (C1 do C23)

\begin{tabular}{|c|c|c|c|c|c|c|c|c|c|c|c|c|c|c|c|c|c|c|}
\hline & $\mathrm{F} 1$ & $\mathrm{~F} 2$ & F3 & $\mathrm{F} 4$ & F5 & F6 & F7 & F8 & F9 & F10 & F11 & $\mathrm{F} 12$ & F13 & F14 & F15 & F16 & F17 & F18 \\
\hline $\mathrm{C} 1$ & & & & & & & & & & & & & & & & & & \\
\hline $\mathrm{C} 2$ & & & & & & & & & & & & & & & & & & \\
\hline C3 & & & & & & & & & & & & & & & & & & \\
\hline $\mathrm{C} 4$ & & & & & & & & & & & & & & & & & & \\
\hline C5 & & & & & & & & $\mathrm{X}$ & & & & & & & & & & \\
\hline C6 & & & & $\mathrm{X}$ & & & & & & & & & & & & & & \\
\hline C7 & & & & & & & & & & & $\mathrm{X}$ & & & & & & & \\
\hline $\mathrm{C} 8$ & & & & & & & $\mathrm{X}$ & & & & & & & & & & & $\mathrm{X}$ \\
\hline $\mathrm{C} 9$ & & & & & & & & & & & $\mathrm{X}$ & & & & & & & \\
\hline $\mathrm{C} 10$ & & & & & & & $\mathrm{X}$ & & & & & & & & & & & $\mathrm{X}$ \\
\hline C11 & & & & & & & & & & & & $\mathrm{X}$ & & & & $\mathrm{X}$ & & \\
\hline $\mathrm{C} 12$ & & & & & & & & & & & & & & & & & & \\
\hline $\mathrm{C} 13$ & & & & & & & & & & & $\mathrm{X}$ & & & & & & & \\
\hline C14 & & $\mathrm{X}$ & & & & $\mathrm{X}$ & & & & & & & & & & & & \\
\hline C15 & $\mathrm{X}$ & & & & $\mathrm{X}$ & & & & & & & $\mathrm{X}$ & & & & & & \\
\hline C16 & & & & & & & & & & & & & & & $\mathrm{X}$ & & $\mathrm{X}$ & \\
\hline C17 & & & & & & & & & & $\mathrm{X}$ & & & & & $\mathrm{X}$ & & & \\
\hline C18 & & & $\mathrm{X}$ & & $\mathrm{X}$ & $\mathrm{X}$ & & & & & & & $\mathrm{X}$ & & & $\mathrm{X}$ & & \\
\hline C19 & & & & & & & & & & & & & & & & & & \\
\hline C20 & & & & & & & & & $\mathrm{X}$ & & & & & & & & & \\
\hline $\mathrm{C} 21$ & & & & & & & & & & & & & & & & & & \\
\hline C22 & & & & & & & & & & & & & & & & & & \\
\hline $\mathrm{C} 23$ & & & & & & $\mathrm{X}$ & & & & & & & & $\mathrm{X}$ & & & & \\
\hline
\end{tabular}

Źródto: Kąkol, Nielek, 2015, s. 305

i innych (2003) ewaluowane witryny były pogrupowane w 10 kategorii treściowych i oceniający nie musieli rozważać rodzaju witryny i charakteru zawartych na niej treści ( 4 brakujące kryteria w zestawie $\mathbf{F}$ należą do grupy „Co to jest?”). Jednocześnie na podstawie badań M. Kąkola i R. Nielka (2015), które zrealizowano 13 lat po ukazaniu się raportu B.J. Fogga i innych, pokazano, że w postawach użytkowników witryn nastąpiła pewna ewolucja. Zaczęli oni bowiem przywiązywać większą wagę do możliwości łatwego wyszukiwania potrzebnej informacji i jej zweryfikowania, co ujawniono w komentarzach do ocen wiarygodności witryn.
S. Aggarwal i inni (2014, s. 2-3) podają 17 kryteriów wiarygodności witryn, które są ważne dla użytkowników w procesie wyszukiwania informacji w Internecie. Definiując i opisując poszczególne kryteria, autorzy uwzględniają stan odpowiednich cech i własności w kontekście automatyzacji oceny wiarygodności witryn w tym procesie. $\mathrm{Z}$ tego powodu w zestawie kryteriów pojawiają się również te, których ocena może być realizowana albo wspierana m.in. przy wykorzystaniu wglądu w strukturę linków witryny, ważonej kombinacji różnych dostępnych na niej funkcji, technik uczenia maszynowego albo społecznej popularności witryny 
(Aggarwal i in., 2014, s. 3). Na zaprezentowanej liście wytłuszczono te kryteria, które były ocenione automatycznie. Pod uwagę wzięto zatem następujące kryteria:

- (K1) Typ strony internetowej odzwierciedlony przez domenę najwyższego poziomu lub przyrostek domeny w adresie strony internetowej (URL).

- (K2) Data ostatniej aktualizacji strony internetowej. - (K3) Czy strona jest pierwotnym, czy wtórnym źródłem informacji?

- (K4) Dostępność informacji kontaktowych. Adres i / lub adres e-mail właściciela strony internetowej.

- (K5) Integralność (spójność) łączy/linków strony internetowej. Strona internetowa $\mathrm{z}$ dodatnim saldem (różnicą) liczby wewnętrznych i zewnętrznych linków jest bardziej wiarygodna. Jeśli witryna liczniej odwołuje się do linków zewnętrznych (ujemne saldo), to w praktyce przekierowuje użytkownika do domeny, której wiarygodność należy ponownie ocenić. Strona internetowa nie powinna mieć także żadnych uszkodzonych linków.

-(K6) Przynależność (afiliacja) witryny (zapisana w jej nagłówku / stopce).
- (K7) Kompletność, dokładność i jednoznaczność informacji na stronie.

- (K8) Wiedza autorów na temat dostarczanych treści. Ich związki ze źródłem publikacji, z grupą docelową, ich punkt widzenia, obiektywność i bezstronność.

- (K9) Cel strony internetowej. Pokazuje intencję właściciela strony, dla której została ona utworzona i jest utrzymywana.

- (K10) Interaktywność strony internetowej. Przyjazna dla użytkownika strona internetowa ułatwia użytkownikowi dostęp do niej czyniąc ją bardziej preferowaną.

- (K11) Projekt strony internetowej (struktura) i jej graficzna estetyka.

- (K12) Jakość informacji na stronie internetowej.

- (K13) Ton strony internetowej. Ironiczny, dowcipny lub przesadny albo nadęty ton informacji na stronie oddziałuje na poziom zaufania, jakim się ona cieszy.

- (K14) Kto dostarcza reklam oraz treści. Ustalenie, czy ta sama osoba lub organizacja dostarcza reklam oraz treści. Obecność lub nieobecność reklamy zmniejsza/zwiększa wiarygodność.

Tabela 3. Porównanie zestawu kryteriów wiarygodności według B.J. Fogga i in. (F1 do F18) oraz S. Aggarwala i in. (K1 do K17)

\begin{tabular}{|c|c|c|c|c|c|c|c|c|c|c|c|c|c|c|c|c|c|c|}
\hline & F1 & F2 & F3 & F4 & F5 & F6 & F7 & F8 & F9 & F10 & F11 & F12 & F13 & F14 & F15 & F16 & F17 & F18 \\
\hline K1 & & & & & & & & & & & $\mathrm{X}$ & & & & & & & \\
\hline K2 & & & & & & & & & & & & & & & & & & \\
\hline K3 & & & & & & & & & & & & & & & & & & \\
\hline K4 & & & & & & & $\mathrm{X}$ & & & & & & & & & & & \\
\hline K5 & & & & & & & & & & & & & & & & & & \\
\hline K6 & & & & & & & & & & & & & & & & & & $\mathrm{X}$ \\
\hline K7 & & & & & & $\mathrm{X}$ & & & & & & & & & & & & \\
\hline K8 & & & & & & & & & $\mathrm{X}$ & & & & & & & & & \\
\hline K9 & & & & $\mathrm{X}$ & & & & & & & & & & & & & & \\
\hline K10 & & & & & & & & & & & & & & & & $\mathrm{X}$ & & \\
\hline K11 & $X$ & $X$ & & & & & & & & & & & & & & & & \\
\hline K12 & & & & & $\mathrm{X}$ & $\mathrm{X}$ & & & & & & & & & $\mathrm{X}$ & & $\mathrm{X}$ & \\
\hline K13 & & & & & & & & & & $\mathrm{X}$ & & & & & & & & \\
\hline K14 & & & & & & & & $\mathrm{X}$ & & & $\mathrm{X}$ & & & & & & & \\
\hline K15 & & & & & & & & & & & & & & & & & & \\
\hline K16 & & & & & & & & & & & & & & $\mathrm{X}$ & & & & \\
\hline K17 & & & & & & & & & & & & & & $\mathrm{X}$ & & & & \\
\hline
\end{tabular}

Źródło: opracowanie wtasne 
-(K15) Określenie wszelkich wymagań oprogramowania, które mogą ograniczać dostęp do informacji.

- (K16) Ranking strony internetowej (np. liczba odwiedzających stronę, liczba unikalnych odwiedzających).

- (K17) Opinia ekspertów na temat wiarygodności domeny (pomocna dla początkującego użytkownika).

Ten zestaw kryteriów oznaczono dalej jako K. Wytłuszczone kryteria oceniono za pomocą narzędzia WebCAST. Narzędzie to dokonuje ewaluacji tych kryteriów wiarygodności witryn na podstawie sześciu miar uzyskanych automatycznie $\mathrm{z}$ różnych aplikacji i wtyczek programistycznych do przeglądarek internetowych (API), takich jak: Alchemy, Web Of Trust (WOT) i Alexa (Aggarwal i in., 2014, s. 5).

W tabeli 3 porównano zestawy $\mathbf{K}$ (wiersze) i $\mathbf{F}$ (kolumny) kryteriów oceny wiarygodności witryn. Podobnie jak poprzednio znakiem „X” oznaczono te kryteria, które występują w obydwu zestawach.

Zestaw kryteriów K pokrywa 76,5\% kryteriów z zestawu $\mathbf{F}$. Z porównania wynika, że w zestawie $\mathbf{K}$ brak jest trzech kryteriów występujących w zestawie F. Są to: (F3) Skupienie informacji, (F12) Funkcjonalność strony i (F13) Obsługa klienta. Uwidacznia to dość istotne z punktu widzenia użytkownika braki w ocenie użyteczności witryny w zestawie S. Aggarwala i innych. Z kolei zestaw kryteriów wiarygodności $\mathbf{F}$ pokrywa 83,3\% kryteriów z zestawu K. $\mathrm{Z}$ porównania wynika, że tym razem $\mathrm{w}$ zestawie $\mathbf{F}$ brak jest czterech kryteriów występujących w zestawie K. Są to: (K2) Data ostatniej aktualizacji, (K3) Pierwotne czy wtórne źródło informacji, (K5) Integralność linków, (K15) Wymagania oprogramowania. W tym przypadku braki w zestawie B.J. Fogga i innych odnoszą się w większości do charakterystyki wewnętrznych danych na witrynie. Pomimo ukazanych różnic (wynikających $\mathrm{z}$ odmiennych celów identyfikacji kryteriów), należy stwierdzić, że oba opisywane zestawy kryteriów oceny wiarygodności K i F są ze sobą zgodne w dużym stopniu.

Autorzy kolejnej pracy (Oltenau i in., 2013) stosują również podejście empiryczne do identyfikacji kryteriów wiarygodności witryn. Zgrupowali oni cechy wiarygodności w dwóch kategoriach: i) cechy treści, które mogą być zmierzone przy użyciu miar zawartości tekstowej witryny (np. występujących części mowy, znaków interpunkcyjnych) oraz miar wyglądu i elementów metainformacyjnych na witrynie (dotyczących np. definicji stylów CSS czy występujących reklam); ii) cechy społeczne, które reprezentują publicznie dostępne informacje na temat witryny na popularnych platformach społecznościowych (np. Facebook, Twitter). W efekcie autorzy opisali zestaw aż 37 miar wiarygodności. Następnie stosując trzy różne testy statystyczne, wybrano spośród nich 22 miary, które mają największą wartość dyskryminacyjną dla oceny wiarygodności witryn. Porównując ten zestaw miar z przytoczonymi poprzednio, można stwierdzić, że występują w nim tylko następujące miary wiarygodności witryn: Czytelność tekstu (F17, C16), Stronniczość informacji (F9), Typ witryny/domeny (K1) oraz Ranking popularności witryny (K16). Tak duże różnice pomiędzy opisywanym zestawem a pozostałymi wynikają prawdopodobnie $\mathrm{z}$ faktu, że zestaw miar zidentyfikowanych przez A. Oltenau i innych (2013) posłużył do automatyzacji oceny wiarygodności. Dlatego zawiera on miary, które mogą być obliczone za pomocą procedur komputerowych opierających się na algorytmach uczenia maszynowego.

\section{Dyskusja}

D okonujące się zmiany $w$ środowisku informacyjnym oraz $\mathrm{w}$ potrzebach informacyjnych organizacji i indywidualnych użytkowników Internetu powodują konieczność ich monitorowania. Niezbędne staje się uwzględnianie kolejnych kryteriów oceny wiarygodności witryn internetowych podczas jej ewaluacji w praktyce. Różne podejścia do identyfikacji kryteriów oceny wiarygodności witryn internetowych pozwalają na stworzenie rozmaitych zestawów tych kryteriów. Jednak zróżnicowanie pomiędzy poszczególnymi zestawami nie jest zbyt duże. Na przykład wygenerowany przez A. Czerwińskiego $\mathrm{w}$ podejściu intuicyjnym zestaw kryteriów pokrywa blisko 78\% kryteriów empirycznego zestawu B.J. Fogga i innych. Wyjątek pod tym względem stanowi zestaw miar zaproponowanych przez A. Oltenau i innych, który odbiega od pozostałych ze względu na zakładaną możliwość automatyzacji pomiaru wiarygodności.

W tym miejscu warto wskazać, że możliwości automatycznej oceny wiarygodności witryn są ograniczone do niektórych obszarów ewaluacji oraz wynikają z dostępności i jakości narzędzi oceny. Najbardziej predestynowane obszary automatyzacji to ilościowa ocena zamieszczonych treści oraz ocena stanu infrastruktury witryny. Ilościowa ocena treści bazuje na wyżej przedstawionej statystycznej analizie tekstu, ocenie wyglądu witryny na podstawie metainformacji oraz ocenie popularności witryny, w tym w mediach społecznościowych (Oltenau i in., 2013, s. 561-562). Bierze się także pod uwagę rodzaj oraz charakter wewnętrznych i zewnętrznych linków na witrynie (Aggarwal i in., 2014, s. 3). Z kolei ocena stanu infrastruktury opiera się na możliwych do pomiaru wskaźnikach opisujących jej dostępność czy zabezpieczenie. Do uzyskania określonych miar i wskaźników wykorzystuje się gotowe oprogramowanie. Są to w szczególności analizatory witryn i analizatory ruchu (Czerwiński, Krzesaj, 2018, s. 137-138), a także wymienione już poprzednio różne wtyczki do przeglądarek (API) oraz dane $\mathrm{z}$ baz danych. Większość tych narzędzi i danych służy przede wszystkim do optymalizacji witryn pod kątem wyszukiwarek (ang. Search Engine Optimization - SEO). Ich możliwości i zróżnicowana jakość ${ }^{1}$ nie są zatem dostosowane wprost do oceny wiarygodności witryn. Dlatego przez badaczy wiarygodności tworzone są specjalizowane narzędzia własne, jak np. wspomniany WebCAST. Oprócz wymienionych analizatorów witryn i ruchu, ich autorzy wykorzystują dodatkowo dostępne dane na temat wiarygodności witryn uzyskiwane w części na podstawie ocen użytkowników, jak np. wskaźnik Web Of Trust - WOT. 
W ramach podejścia empirycznego do identyfikacji kryteriów oceny wiarygodności witryn internetowych powstały także zróżnicowane zestawy tych kryteriów. Jednak, tak jak to miało miejsce w podejściu intuicyjnym, dysproporcja pomiędzy poszczególnymi zestawami jest niewielka. Największa rozbieżność występuje pomiędzy zestawem kryteriów podanym przez B.J. Fogga i innych (2003) oraz zestawem kryteriów zaprezentowanych przez M. Kąkola i R. Nielka (2015). Bowiem pierwszy zestaw pokrywa ten drugi tylko w $65 \%$. Wynika to $z$ faktu, że współcześni użytkownicy witryn zaczęli przywiązywać większą wagę do możliwości łatwego wyszukiwania potrzebnej informacji i jej zweryfikowania. Powoduje to konieczność uzupełnienia oceny wiarygodności witryn o nowe kryteria, opisujące np. charakter treści internetowych czy też wskazujące na możliwość ich sprawdzenia, które w zestawie B.J. Fogga i innych nie były uwzględnione. Łatwo jest zauważyć, że wszystkie zaprezentowane zestawy oceny wiarygodności witryn są w pełni ogólne. Obejmują bowiem ocenę wiarygodności we wszystkich procesach informacyjnych realizowanych przez organizacje, tzn. w trakcie generowania, gromadzenia, przechowywania, przetwarzania, przesyłania, udostępniania, interpretacji i wykorzystywania informacji. Trzeba jednak zastrzec, że zakres tej ewaluacji jest odmienny. Najwięcej kryteriów występuje dla procesu udostępniania informacji, co wynika z roli witryn internetowych. Najmniej kryteriów zidentyfikowano $\mathrm{w}$ procesach interpretacji i wykorzystywania informacji.

Kryteria oceny wiarygodności uzyskane na podstawie podejścia intuicyjnego są odpowiednie do ewaluacji realizowanej przez wszystkie podmioty, tzn. przez dostawców, administratorów i użytkowników informacji. Kryteria istotne $\mathrm{z}$ punktu widzenia dostawców informacji zostały zgrupowane w wymiarze uczciwość (autentyczność, referencje, wierność, solidność/ rzetelność i poszanowanie cudzej własności). Z kolei kryteria ważne $\mathrm{z}$ punktu widzenia administratorów znajdują się w wymiarze życzliwość (wydajność, niezawodność, dostępność danych, bogactwo informacji, jakość informacji). Kontekstowe kryteria, które charakteryzują kontekst rozwiązywanego problemu/zadania z punktu widzenia indywidualnego użytkownika są zawarte w wymiarze $z$ dolność (doświadczenie, nawyki, styl życia i prywatność). Także w tym wymiarze znajdują się kryteria wiarygodności, które wiążą się z podmiotowym kontekstem procesów informacyjnych realizowanych na witrynie przez dostawców, administratorów i użytkowników informacji (funkcjonalność, bezpieczeństwo, przejrzystość i elastyczność). Oznacza to, że wymienione kryteria będą interpretowane podmiotowo i zapewne subiektywnie przez te podmioty.

Kryteria oceny wiarygodności uzyskiwane w ramach podejścia empirycznego wiążą się z ewaluacją dokonywaną wyłącznie przez użytkowników i dlatego są odpowiednie tylko dla tej grupy.

W podejściu intuicyjnym kryteria oceny wiarygodności witryn są identyfikowane dla określonego celu, na przykład podejmowania decyzji. Może (ale nie musi) to ograniczać elastyczność zidentyfikowanych w ten sposób zestawów kryteriów do określonej grupy witryn internetowych. Na przykład przedstawiony w artykule zestaw kryteriów $\mathbf{W}$ nadaje się do oceny wiarygodności witryn z dowolnego obszaru. Ograniczenie elastyczności nie występuje w ogóle w przypadku wykorzystania podejścia empirycznego (zestawy F, C i K). W prezentowanych $\mathrm{w}$ artykule badaniach użytkownicy oceniali bowiem wiarygodność witryn $\mathrm{z}$ dowolnego obszaru.

Zidentyfikowane $\mathrm{w}$ artykule zestawy kryteriów oceny wiarygodności witryn ujawniły dodatkowo, że pojawiająca się możliwość automatyzacji pomiaru wywołuje ich głębszą dywersyfikację. Wynika ona z jeszcze niezbyt dużego potencjału automatycznych metod i narzędzi oceny wiarygodności witryn. W konsekwencji ocena ta będzie się składać z dwóch części. Pierwsza - możliwa tylko do realizacji przez człowieka i dokonywana oraz rozpowszechniana albo przez ekspertów w tej dziedzinie, albo przez samych użytkowników Internetu. Druga - dokonywana przez internetowe roboty, lecz tylko w pewnym ograniczonym zakresie kryteriów. Pełny obraz wiarygodności witryn będzie wymagać realizacji obydwu tych ocen.

\section{Podsumowanie}

$\mathbf{Z}$ aprezentowane zestawy oceny wiarygodności witryn są w pełni ogólne, tzn. obejmują ewaluację wiarygodności we wszystkich procesach informacyjnych realizowanych za ich pomocą $\mathrm{w}$ organizacji. Kryteria oceny wiarygodności uzyskane na podstawie podejścia intuicyjnego są odpowiednie do ewaluacji realizowanej przez wszystkie podmioty, tzn. przez dostawców, administratorów i użytkowników informacji na witrynach. Kryteria oceny wiarygodności uzyskane w ramach podejścia empirycznego są odpowiednie wyłącznie dla użytkowników witryn.

Przedstawione w artykule zestawy kryteriów oceny wiarygodności nadają się do ewaluacji witryn $z$ dowolnego obszaru. Można je zatem uznać za elastyczne. Pokazano, że stosując podejścia intuicyjne i empiryczne do identyfikacji kryteriów oceny wiarygodności witryn internetowych, uzyskuje się zróżnicowane zestawy tych kryteriów. W efekcie, w praktyce ewaluacji, konieczne będzie dobranie mieszanki kryteriów z poszczególnych zestawów. Skład takiej mieszanki powinien być uzależniony od takich czynników, jak: i) kategoria witryny i jej funkcje; ii) podmiot i jego rola $\mathrm{w}$ procesie dokonywania oceny wiarygodności; iii) wykorzystanie tej oceny w określonym kontekście. Dlatego problem doboru odpowiedniej mieszanki kryteriów ewaluacji wiarygodności witryn wymaga dalszych badań. W pierwszym etapie tych badań trzeba będzie ustalić ważność poszczególnych kryteriów z punktu widzenia trzech wyżej wymienionych czynników. Następnie, przy użyciu zestawów kryteriów najistotniejszych z tych różnych perspektyw, można będzie oceniać wiarygodność witryn i zaproponować ich doskonalenie. 


\section{dr hab. Adam Czerwiński, prof. uczelni \\ Uniwersytet Opolski \\ Wydziat Ekonomiczny \\ ORCID: 0000-0001-8666-8164 \\ e-mail: adam.czerwinski@uni.opole.pl}

\section{Przypis}

1) Jako przykład różnic w wynikach pomiaru niech posłuży wskaźnik czasu ładowania witryny Uniwersytetu Opolskiego (www.uni.opole.pl), który w przeprowadzonych badaniach wahał się od 8,3 sekundy (narzędzie Webpagetest) do 10,98 sekund (narzędzie Pingdom), czyli o 24,4\% (Czerwiński, Krzesaj, 2018, s. 141).

\section{Bibliografia}

[1] Aggarwal S., Van Oostendorp H., Reddy Y.R., Indurkhya B. (2014), Providing Web Credibility Assessment Support, Proceedings of the 2014 European Conference on Cognitive Ergonomics, ACM, New York, pp. 1-8.

[2] Ballou D., Pazer H. (1985), Modelling Data and Process Quality in Multi-input, Multi-output Information Systems, „Management Science”, Vol. 31, No. 2, pp. 150-162.

[3] Czerwiński A. (2016a), Ocena wiarygodności serwisów www polskich uniwersytetów, „Praktyka i Teoria Informacji Naukowej i Technicznej", Nr 22(2-3), s. 44-55.

[4] Czerwiński A. (2016b), Ocena wiarygodności internetowych serwisów ubezpieczeniowych $w$ Polsce, Prace Naukowe Uniwersytetu Ekonomicznego we Wrocławiu, Nr 425, s. $63-72$.

[5] Czerwiński A., Krzesaj M. (2018), Ocena jakości informacji $w$ Internecie, Studia i Monografie Nr 554, Wydawnictwo Uniwersytetu Opolskiego, Opole.

[6] Eppler M. (2006), Managing Information Quality. Increasing the Value of Information in Knowledge-intensive Products and Processes, Springer, Berlin.

[7] Fogg B., Soohoo C., Danielson D.R., Marable L., Stanford J., Tauber E.R. (2003), How do Users Evaluate the Credibility of Web sites?: A Study With Over 2,500 Participants, Proceedings of the 2003 Conference on Designing for User Experiences, ACM, New York, pp. 1-15.

[8] Gefen D., Karahanna E., Straub D.W. (2003), Trust and TAM in Online Shopping: An Integrated Model, „MIS Quarterly", Vol. 27, No. 1, pp. 51-90.

[9] Gefen D. (2002), Reflections on the Dimensions of Trust and Trustworthiness among Online Consumers, „ACM SIGMIS Database", Vol. 33, No 3, pp. 38-53.

[10] Kąkol M., Nielek R. (2015), What Affects Web Credibility Perception? An Analysis of Textual Justifications, „Computer Science”, Vol. 16, No. 3, pp. 295-310.

[11] Knight S., Burn J. (2005), Developing a Framework for Assessing Information Quality on the World Wide Web, „Informing Science Journal”, Vol. 8, pp. 159-172.

[12] Lucassen T., Muilwijk R., Noordzij M.L., Schraagen J.M. (2013), Topic Familiarity and Information Skills in Online Credibility Evaluation, „Journal of the American
Society for Information Science and Technology", Vol. 64, No. 2, pp. 254-264.

[13] Oltenau A., Peshterliev S., Liu X., Aberer K. (2013), Web Credibility: Features Exploration and Credibility Prediction, [in:] P. Serdyukov et al. (eds.), Proceedings of the European Conference on IR Research ECIR 2013, Lecture Notes in Computer Science, Vol. 7814, Springer Verlag, Berlin, Heidelberg, pp. 557-568.

[14] O'Reilly III C. (1982), Variations in Decision Makers - Use of Information Source: The Impact of Quality and Accessibility of Information, „Academy of Management Journal”, Vol. 25, No. 4, pp. 756-771.

[15] Schwarz J., Morris M. (2011), Augmenting Web Pages and Search Results to Support Credibility Assessment, Proceedings of the SIGCHI Conference on Human Factors in Computing Systems CHI '11, ACM, New York, pp. 1245-1254.

[16] Wand Y., Wang R. (1996), Anchoring Data Quality Dimensions in Ontological Foundations, „Communications of the ACM”, Vol. 39, No. 11, pp. 86-95.

[17] Wang R. (1998), A Product Perspective on Total Data Quality Management, "Communications of the ACM", Vol. 41, No. 2, pp. 58-65.

[18] Wang R., Strong D. (1996), Beyond Accuracy: What Data Quality Means to Data Consumers, „Journal of Management Information Systems", Vol. 12, No. 4, pp. 5-33.

\section{Identification and Comparison of Evaluation Criteria for Credibility of Internet Services and Websites}

\section{Summary}

The aim of the article is to both identify and compare different sets of evaluation criteria for credibility of internet services and websites. The questions asked by the author in the above work are as follows:

1. Does application of various approaches to identify and define criteria of evaluating the credibility of internet services and websites allows one to obtain the same frame of evaluation that are general, valid and elastic?

2. Does it lead to creation of various sets of the abovementioned criteria?

To answer the abovementioned questions, the author of the article shows possible approaches to identify the criteria for evaluating the credibility of websites: intuitive, theoretical and empirical. On this basis the author of this article shows chosen examples of sets of valid evaluation criteria. Application of comparative analysis allowed the author to reveal how varied the evaluation criteria are and allowed to identify the ones that are most general, valid and elastic. The results of the comparison of different criteria sets for credibility evaluation could be applied in practice to construct different tools for evaluating the credibility of websites and internet services.

\section{Keywords}

credibility assessment, criteria, comparison, site 